\title{
Geochemical study of the early cretaceous Fahliyan oil reservoir in the northwest Persian Gulf
}

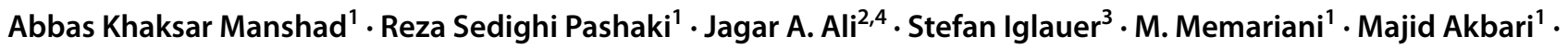 \\ Alireza Keshavarz ${ }^{3}$
}

Received: 14 February 2021 / Accepted: 30 April 2021 / Published online: 14 May 2021

(c) The Author(s) 2021

\begin{abstract}
Three crude oil samples from the Fahliyan Formation in 'KG' and 'F' fields in the northwest Persian Gulf, namely KG-031, F9A-3H and F15-3H for the geochemical study. In this study, the physicochemical properties, gas chromatography (GC, GC Mass) and (Detailed Hydrocarbon Analysis) DHA analyses for the collected Fahliyan oils were carried out. The API, Trace Element (Ni, V) and S\% parameters indicated that the Fahliyan oil was generated from a source rock which deposited in reducing environment condition with a carbonate-shale compound lithology. Moreover, low pour point, higher S\% and low viscosity parameters of "KG" sample confirmed the existence of medium oil characteristics in this field. In addition, the geochemical outcomes of GC, GC-MS and DHA analyses indicated that the 'KG' oils are more aromatic compared with 'F' oil; while biomarkers revealed that Fahliyan reservoir oil is highly mature and was formed from a carbonate source rock containing types II, III kerogen. Thus, sterane/hopane biomarkers $\left(\mathrm{C}_{24} / \mathrm{C}_{23}\right.$ and $\mathrm{C}_{22} / \mathrm{C}_{21}$ ratios) revealed that Fahliyan oil originated from carbonate source rocks deposited in an anoxic to dysoxic environment, which is consistent with the above analyses. It was identified that the source rock age is early Cretaceous to late Jurassic. It can be reported that the Fahliyan oils from both fields were generated in the same source rock and have almost the same physical properties, and will have the same production strategy.
\end{abstract}

Keywords Fahliyan formation · Oil-oil correlation · Oil-source rock correlation · Geochemistry · Crude oils

\section{Introduction}

The Persian Gulf, a small sea adjacent to the Indian Ocean, lies between Iran and the Arabian Peninsula (see Fig. 1). The Persian Gulf and its coastal parts contain the major

Abbas Khaksar Manshad

akm113pet@gmail.com

$\bowtie$ Jagar A. Ali

jagar.pet@gmail.com

1 Department of Petroleum Engineering, Abadan Faculty of Petroleum Engineering, Petroleum University of Technology (PUT), Abadan, Iran

2 Department of Petroleum Engineering, Faculty of Engineering, Soran University, Soran, Kurdistan Region, Iraq

3 School of Engineering, Edith Cowan University, Joondalup, WA 6027, Australia

4 Department of Geology, Palacký University, 17. listopadu 12, Olomouc 77146, Czech Republic quantities of crude oil and natural gas, approximately 715 billion barrels of crude oil (2/3 of the world's proven oil reserves) and $2462 \mathrm{tcf}$ of gas (1/3 of the total verified world gas reserves) (Rabbani 2014; Baniasad et al. 2017). In this area, the presence of many significant regional caprocks, considerable source rock beds, great carbonate reservoirs, huge anticlinal traps and continuous sedimentation are the main factors turning this gulf into an excellent region for hydrocarbon accumulations (Rabbani et al. 2014). One part of this region is the Fahliyan Formation in the NW of the Persian Gulf, and many significant oil reservoirs were discovered there in the last 50-60 years (Soleimani et al. 2017). Thus, the presence of widespread reservoir development in combination with the organic-rich deepwater Garau formation among other source rocks turned this formation into an important target for hydrocarbon exploration (Adabi et al. 2010).

The stratigraphic and sedimentary environments of the Fahliyan Formation were reported by several authors including James and Wynd (1965), Shakib (1994), Moallemi 


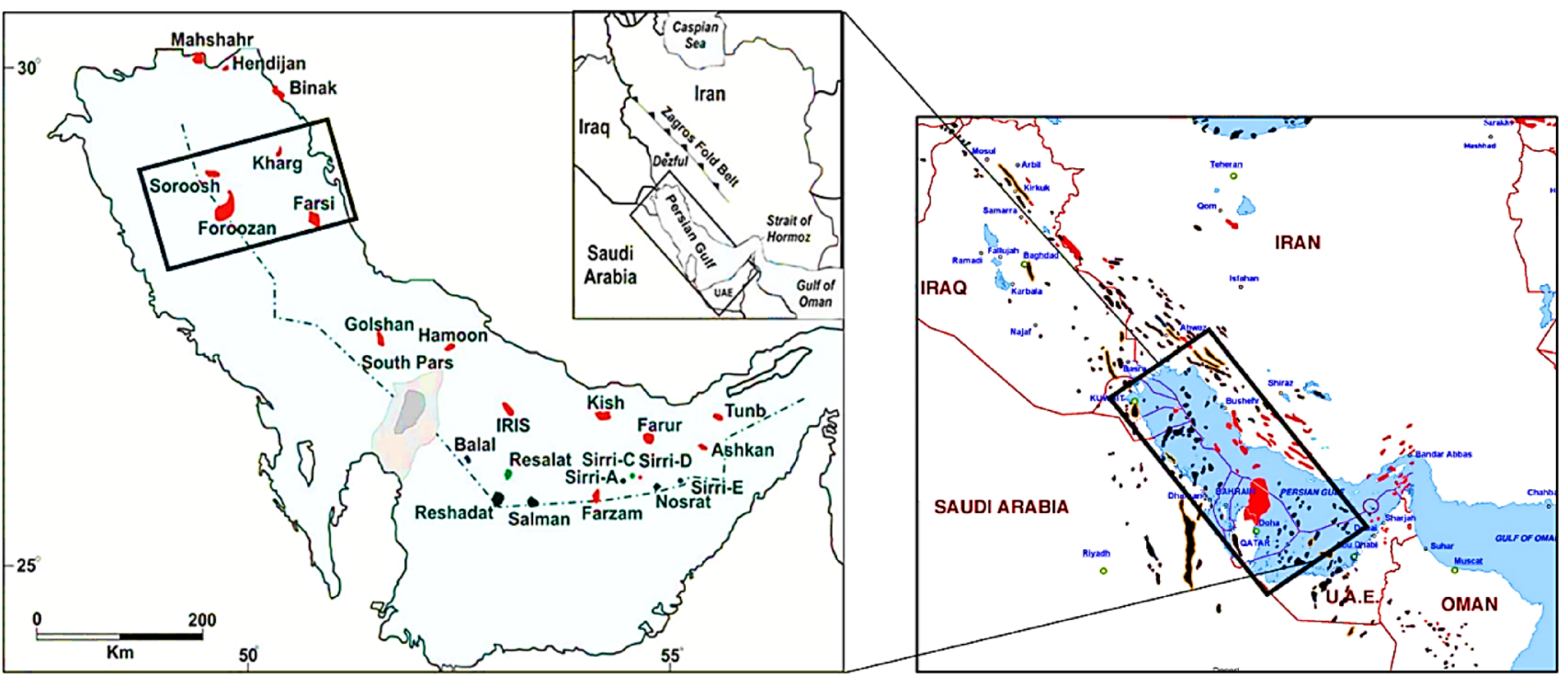

Fig. 1 Map showing the Northwest Persian Gulf area (Southwest Iran) studied

(2000). In recent facies analysis, it was stated that the Fahliyan Formation in some sections of Southwest Iran is composed of both, shallow and deep marine facies; restricted marine barriers, and open marine shallow facies (deposited on a carbonate shelf platform), and pelagic and calciturbidite deep marine facies (deposited on the intrashelf basin) (Kondroud and Lasemi 2008).

However, the geology of this formation is well described (see Table 1) (Kavoosi et al. 2006; Jamalian et al. 2010; Feghhi et al. 2012; Abyat et al. 2012, 2014; Mahbaz et al. 2012; Shakeri and Parham 2013; Jamalian and Adabi 2014; Soleimani et al. 2017), considerable uncertainty related to the maturity and quality of source rocks still exists which may affect on the reliability of geochemical models. Consequently, this study focuses on characterizing the Fahliyan Formation with regards to the depositional environment, organic matter, source rock, and thermal maturity in two fields in the Iranian Fars sector. Hence, a detailed organic geochemical analysis with bulk geochemical parameters for the Fahliyan Formation oils was performed here.

\section{Geological setting}

Fahliyan Formation within the surface section of the Kuh-e Siah was overlaid by the Lower Cretaceous Gadvan Formation with a conformable contact but it unconformably covers the Upper Jurassic Hith Formation (see Fig. 2) (Soleimani et al. 2017). The Kuh-e Siah anticline can be seen within the Fars Salient in the south of the Zagros fold-thrust belt (ZFTB) and is composed of a sequence of heterogeneous recent Neoproterozoic-Phanerozoic sedimentary cover strata with a thickness of about 7-12 km (Aubourg 2004). ZFTB is the re-shaped form of the Zagros sedimentary basin. According to the current positions, this basin was stretched out over the northeast of the Afro-Arabian continental margin which develops the Zagros orogeny from the closure of the NeoTethys due to three geotectonic events including the sliver emplacement of oceanic crust over the Afro-Arabian continental margin, Afro-Arabian continental collision with the Iranian plates, and subduction of the Neo-Tethyan oceanic crust beneath the Iranian plates (Sherkati et al. 2005; Bahroudi and Koyi 2003). Generally, the ZFTB is extended by about $2000 \mathrm{~km}$ from the southeast of Turkey through the north of Syria and northeast of Iraq to southwestern Iran. Meanwhile, it is one of the most essential tectonic units in Iran which has a length of greater than $1500 \mathrm{~km}$ and 100-300 km in width (Abyat et al. 2012).

Zagros Orogen is composed of three separate parallel tectonic zones, such as Zagros imbricate zone (ZIZ), Urumieh Dokhtar magmatic assemblage (UDMA) and Zagros fold-thrust belt (ZFTB). ZFTB as an external part of the orogen extends parallel to the southwest of ZIZ by $300 \mathrm{~km}$ in width which contains some salients and recesses from northwest to southeast, such as Kirkuk recess in northern Iraq, Lorestan salient, Dezful recess and Fars salient in southwestern Iran (Alavi 2007, Kamali et al. 2013; Rbbani et al. 2014). From west, east, northeast and southeast, the Fars zone has been surrounded by Kazerun Fault, Zendan Fault, High Zagros Fault and Persian Gulf coastal line, respectively (Sabouhi et al. 2009). This zone is mainly characterized by the presence of $15-20 \mathrm{~km}$ anticlines which was developed from bending mechanism on the Hormuz Salt. However, these anticlines 
Table 1 Summary of some previews works about the geochemistry of the Fahliyan Formation

\begin{tabular}{llll}
\hline Author & Year Function Outcome
\end{tabular}

Feghhi et al. (2012) Sedimentological analysis

Shakeri and Parham (2013) Characterization and quality control

Sabouhi et al. (2009) Facies analysis

Adabi et al. (2010) Geochemistry analysis

Jamalian et al. (2010) Characterization analysis

Abyat et al. (2012) Lithostratigraphy \& microbiostratigraphy

Abyat et al (2014) Microfacies analysis

Mahbaz et al. (2012) Rock physics modeling

Abedpour et al. (2016) Biostratigraphic \& lithostratigraphic analysis

Jamalian and Adabi (2014) Geochemistry and microfacies analysis
The Fahliyan Formation was distinguished as a high-quality reservoir in the Southwest Iran due to occurring many effective diagenetic processes, such as stylolitization, micritization, silicification, dissolution, bioturbation, and cementation

They stated that there were various diagenetic factors which have impacts on the quality of this reservoir in shallow and deep burial, meteoric, and marine environments, such as dissolution, dolomitization, compaction, fracturing, and cementation

It consists of one shelly facies and 13 carbonate microfacies, and subdivided into four facies groups according to the depositional settings, such as a lagoon, open marine, tidal-flat, and bar

10 microfacies were identified by an analysis of the sequence stratigraphy, depositional environment, and geochemistry of Fahliyan formation

Identifying 25 microfacies which were divided into four deposition belts include the lagoon, tidal flat, shoal, and open-marine

According to the identified foraminifers and algae fossil species, they identified two biozones, such as Orbitolina-Choffattella Salpingoporella and Pseudocyclammina lituus Arabica

They recognized 18 microfacies, which subdivided into pelagic, hemipelagic, inner and middle shelf, and coastal deposits, and outlined three biozones according to the discovered microfossils, such as Beriasian, Barremian, and Valanginain-Hauterivian

The developed model showed that the shale and limestone have various trends but marl was always laid stable between them

Depending on the distribution of recognized algae and foraminifers, only 3 biozones were recognized, such as pseudochrysalidina conica, calpionella alpine, and pseudocyclammina lituusTrocholina sp. assemblage zones

Fahliyan Formation was build up in a shallow warm-water environment in the age of early Cretaceous; its porosity and original texture were mainly influenced by dissolution, dolomitization and cementation diagenetic processes

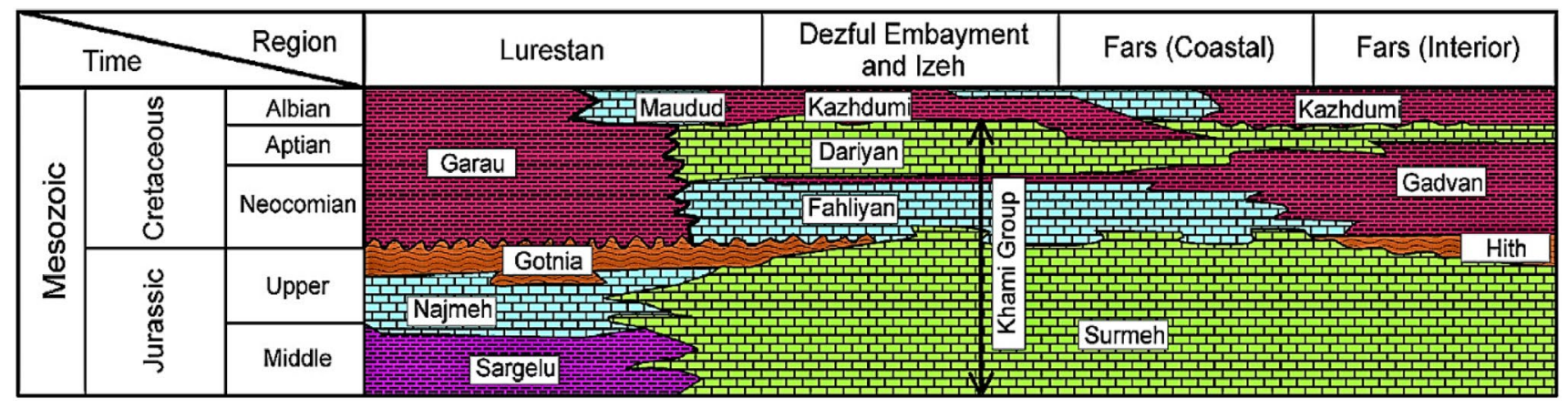

Fig. 2 Lithostratigraphic chart of the Mesozoic of the Zagros Basin (Alavi 2007)

have been divided into five different trends by thrust faults with the presence of salt domes (Bordenave 2003). The impact of these salt domes on the anticline can be used as the most important structural features in this region.
Even, the trapping style of hydrocarbon in this region varies to that formed in Embayments and regions because its source rock developed more gas and less oil accumulations (Schwarzbauer et al. 2000; Amijaya et al. 2006). 


\section{Samples and methods}

Three crude oil samples were collected from KG-031 well in 'KG' oilfield and F9A-3H and F15-3H wells in 'F' oilfield in the northwest of the Parisian gulf for analysis in this study (see Fig. 1). The density (API) of oil samples was measured at $15.6{ }^{\circ} \mathrm{C}\left(60{ }^{\circ} \mathrm{F}\right)$ using an Anton Paar density meter (Anton Paar DMA5300M). In addition, the kinematic viscosity of the crude oils was measured at three different temperatures $\left(10{ }^{\circ} \mathrm{C}, 20^{\circ} \mathrm{C}\right.$ and $\left.40{ }^{\circ} \mathrm{C}\right)$ using VST-2400 viscometer.

Furthermore, selected crude oils were subjected to a series of analytical tests (Sulfur content, nickel and vanadium ratios, pour points, cut points and 'SARA' = Saturate, Aromatic, Resin and Asphaltene fractionation). The sulfur, carbon, hydrogen and nitrogen contents of oil samples were measured using a LECO CHNS-932 analyzer at $1000{ }^{\circ} \mathrm{C}$ burning temperature in the presence of oxygen. The nickel and vanadium ratios were measured using atomic absorption spectrophotometry. Thus, $2-3 \mathrm{~g}$ of each sample were treated overnight with an equal weight of concentrated sulfuric acid with the purity of $95-99 \%$ total mass. After recovering this acid by heating on a hot plate with gradual temperature increase, the samples were ashed with gradually increased temperature up to $450{ }^{\circ} \mathrm{C}$ and were dried overnight. The ashed samples were then heated on a hot plate for 10-20 min and $1 \mathrm{ml}$ of concentrated aqueous HCI was added to the solution until it was clear and yellow, and subsequently filtered. The resulting solution was diluted and analyzed for $\mathrm{Ni}$ and Va on a Varian spectrum 14.4-30 atomic absorption spectrophotometer.

In the SARA analysis, the asphaltene fraction was precipitated by addition of $n$-heptane with a purity of 98\%. The asphaltene-free samples and the saturate fractions were analyzed via gas chromatography in order to obtain the distribution of alkanes and Pristane (Pri), Phytane (Phy), C17, C18, etc. For conducting the gas

Table 2 Instrument specifications and test conditions of gas chromatography (GC) analysis

\begin{tabular}{ll}
\hline Parameter & Range \\
\hline GC model & Varian-Cp-3800 \\
Capillary column & CP-Sil $5 \mathrm{CB}(25 \mathrm{~m} \times 25 \mu \mathrm{m})$ \\
carrier gas & Helium $(5 \mathrm{ml} / \mathrm{min})$ \\
Detector & FID \\
Sample size & $0.2 \mu \mathrm{l}$ \\
Injector temp & $310^{\circ} \mathrm{C}$ \\
Oven temp & $40{ }^{\circ} \mathrm{C}\left(4{ }^{\circ} \mathrm{C} / \mathrm{m}\right.$ increasing rate $)$ \\
Final temp & $290{ }^{\circ} \mathrm{C}$ \\
Detector temp & $310{ }^{\circ} \mathrm{C}$ \\
\hline
\end{tabular}

chromatography (GC) analysis, we followed the procedures drawn by Schwarzbauer et al. (2000), Amijaya et al. (2006). The asphaltene-free sample was injected into the $\mathrm{GC}$ in a heated port linked with a fused-silica cross-linked methyl silicone gum with the instrument specifications and test conditions shown in Table 2. Finally, the complementary geochemical analysis and biomarker finger printing were carried out on of saturate and aromatic fractions of oil samples using gas chromatography-mass spectrometry (GC-Mass) analysis with the instrument specifications and test conditions shown in Table 3.

\section{Results and discussion}

\section{Hydrocarbon source}

Table 4 shows the various measured physical properties of crude oils. The sulfur content and $\mathrm{V} /(\mathrm{Va}+\mathrm{Ni})$ ratio of the analyzed samples were ranged between 1.32 to $2.24 \mathrm{~mol} \%$ and 62 to $73 \mathrm{~mol} \%$, respectively. According to Lewan (1984), when the $\mathrm{Va} /(\mathrm{Va}+\mathrm{Ni})$ ratio is greater than $0.5 \%$, it is an oxygen-free environment. $\mathrm{Va} /(\mathrm{Va}+\mathrm{Ni})$ ratios for the oil samples from the KG-031, F15-3H, and F9-3H wells were $72.5 \%, 67.7 \%$ and $72.3 \%$, respectively. When considering these ratios in combination with the sulfur contents, it can be concluded that all oil samples were formed from a single source rock which deposited in a reducing environment with calcareous lithology as shown in Fig. 3 (Lewan 1984).

When plotting sulfur content versus API gravity of Fahliyan oils, in accordance with Mashhadi and Rabbani (2015),

Table 3 Instrument specifications and test conditions of gas chromatography-mass spectroscopy (GC-MS) analysis

\begin{tabular}{ll}
\hline Parameter & Range \\
\hline GC model & Varian-Cp-3800 \\
Capillary column & DB- $5(20 \mathrm{~m} \times 25 \mu \mathrm{m})$ \\
carrier gas & Helium $(5 \mathrm{ml} / \mathrm{min})$ \\
Detector & FID \\
Sample size & $0.1 \mu \mathrm{l}$ \\
Injector temp & $280{ }^{\circ} \mathrm{C}$ \\
Oven temp & $50{ }^{\circ} \mathrm{C}\left(5^{\circ} \mathrm{C} / \mathrm{m}\right.$ increasing rate $)$ \\
Final temp & $280{ }^{\circ} \mathrm{C}$ \\
Detector temp & $310^{\circ} \mathrm{C}$ \\
Mass spectrometer & $\mathrm{DSQ}$ model \\
Ione source & $70 \mathrm{eV}$ \\
scanning mode & $\mathrm{SIM}$ \\
Scanning rate & $0.4 \mathrm{~s} / 500 \mathrm{amu}$ \\
Vacuum system & Turbo mol. pump $\left(1 \times 10^{-7}\right.$ mil torr $)$ \\
\hline
\end{tabular}


Table 4 Physical properties of oil samples

\begin{tabular}{|c|c|c|c|c|c|c|c|c|c|c|}
\hline \multirow[t]{2}{*}{ Well } & \multicolumn{3}{|c|}{ Viscosity (cP) } & \multirow[t]{2}{*}{ Sulfur (wt.\%) } & \multirow[t]{2}{*}{ Pour point $\left({ }^{\circ} \mathrm{C}\right)$} & \multirow[t]{2}{*}{$\mathrm{Va}(\mathrm{ppm})$} & \multirow[t]{2}{*}{ NI (ppm) } & \multirow{2}{*}{$\begin{array}{l}\mathrm{V} /(\mathrm{V}+\mathrm{NI}) \\
(\mathrm{wt} . \%)\end{array}$} & \multirow[t]{2}{*}{$\mathrm{API}^{\circ}$} & \multirow[t]{2}{*}{ Density $\left(\mathrm{kg} / \mathrm{m}^{3}\right)$} \\
\hline & $10^{\circ} \mathrm{C}$ & $20^{\circ} \mathrm{C}$ & $40^{\circ} \mathrm{C}$ & & & & & & & \\
\hline KG-031 & 12 & 8 & 6.5 & 2.24 & -40 & 19 & 7.2 & 72.5 & 30.4 & 876 \\
\hline F15-3H & 41 & 21 & 12.2 & 1.95 & -17 & 21 & 10 & 67.7 & 33.6 & 857 \\
\hline F9-3H & 18 & 11 & 8 & 1.32 & -23 & 23 & 8.8 & 72.3 & 31.3 & 869 \\
\hline
\end{tabular}

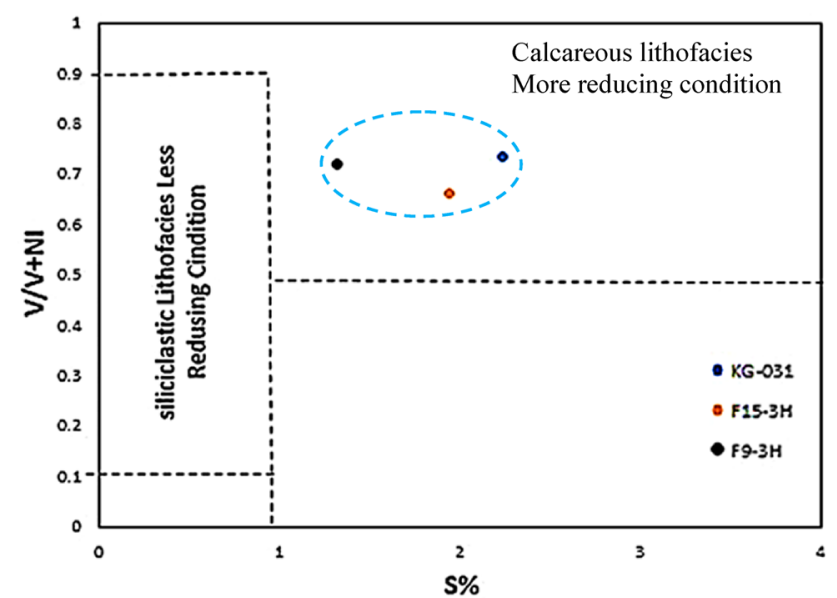

Fig. $3 \mathrm{~V} /(\mathrm{V}+\mathrm{Ni})$ ratio versus Sulfur content of analyzed crude oils

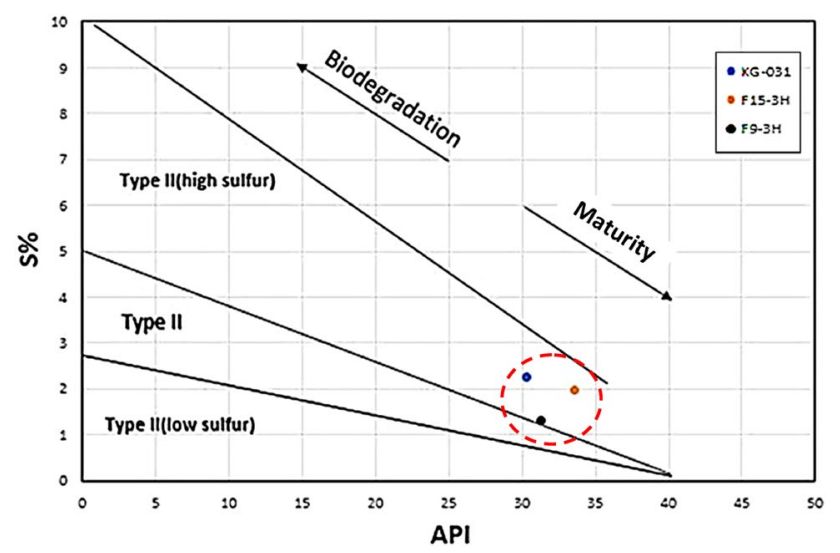

Fig. 4 Cross-plot showing the relation between API gravities and Sulfur contents of the crude oils tested it is clear that these oils were generated from a matured source rock containing kerogen type II (see Fig. 4). According to the API standard ratios, the Fahliyan oils can be classified as light to medium oils with the presence of high sulfur contents ranging from 1.32 to $2.24 \mathrm{wt} . \%$.

\section{Oil-oil correlations}

Bulk properties of the analyzed oil samples indicate that the ' $\mathrm{KG}$ ' oil is a medium oil with an API gravity of $30.4^{\circ}$ and the ' $F$ ' oils are light oils with API gravities ranging from 31.3 to $33.6^{\circ}$, as shown in Table 4. Furthermore, it is clear that the Fahliyan oils consist of different components. Thus, the bulk composition of studied oils is generally dominated by higher concentrations of saturated components (43.39-60.09 mol\%) compared to aromatic, resin, and asphaltene compounds (with various ratios from 1.24 to $38.62 \mathrm{~mol} \%$ ) (see Table 5). The ratio of saturated to aromatic hydrocarbon is higher than 1.0 for all samples, and the saturate, aromatic, resin and asphaltene fractions are small with ratios $<70 \mathrm{~mol} \%$. Hence, they were buried at shallow to medium depth (Liu et al. 2017).

Fahliyan oils extracted from two extracted oil reservoirs were further investigated using cut point analysis. In this way, they were distilled 5\% intervals with respect to yield percent of boiling points. When comparing the cut points of these oils, it can be seen that there is a close resemblance in the distribution patterns between the oil samples from F15-3H and F9-3H wells (see Fig. 5). However, the KG-031 oil shows a clear difference from $15 \%$ yield onward, which indicates the presence of heavier oil components when compared to the ' $F$ ' oil. This is true with respect to the weight percent of hydrocarbon fractions and API degrees discussed above.
Table 5 Geochemical data and gross chemical composition of crude oils tested

\begin{tabular}{lllllcc}
\hline Oil Sample & Oilfield & Saturates (mol\%) & $\begin{array}{l}\text { Aromatics } \\
(\mathrm{mol} \%)\end{array}$ & Sat/Aro & Resins (mol\%) & $\begin{array}{l}\text { Asphaltenes } \\
(\mathrm{mol} \%)\end{array}$ \\
\hline KG-031 & KG & 49.05 & 38.62 & 1.27 & 8.69 & 3.64 \\
F9A-3H & F & 60.09 & 20.43 & 2.94 & 18.24 & 1.24 \\
F15-3H & F & 43.39 & 33.51 & 1.28 & 17.64 & 5.46 \\
\hline
\end{tabular}




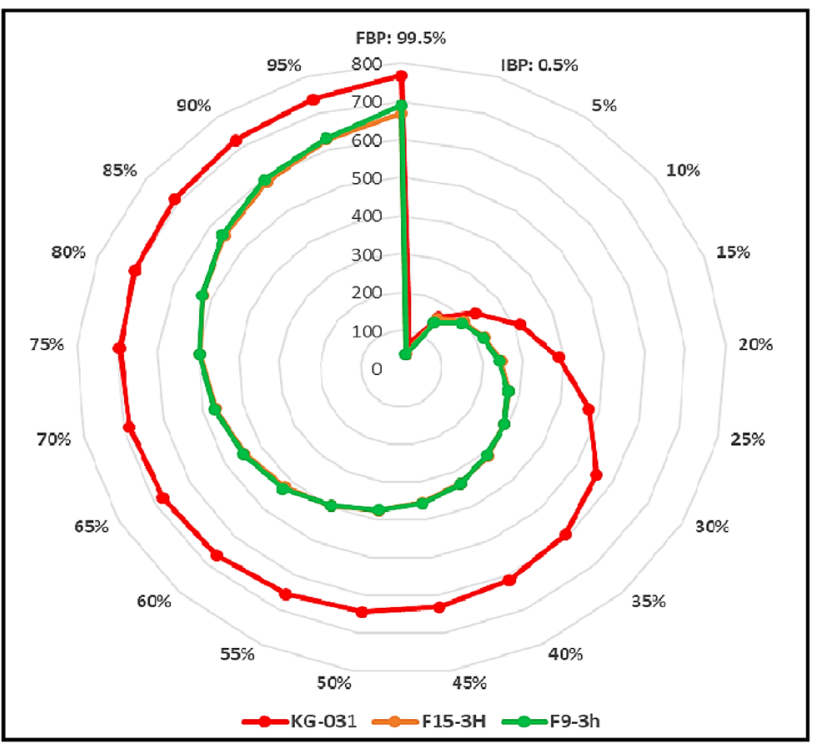

Fig. 5 Comparison distribution of cut points of crude oils tested

DHA results were divided into five various groups including paraffines, aromatics, iso-paraffines, naphthenes and olefins (see Fig. 6). As it can be seen, the percentage of paraffinic hydrocarbon from both $\mathrm{F} 15-3 \mathrm{H}$ and $\mathrm{F} 9-3 \mathrm{H}$ wells was higher than what measured from the ' $\mathrm{KG}$ ' oil. However, the aromatic ratio in ' $\mathrm{KG}$ ' oil is higher compared with the 'F' oils. In summary, it can be stated that the Fahliyan oils are mainly composed of paraffinic and iso-paraffinic hydrocarbons with low carbon content.

\section{Organic matter and depositional environment}

Gas chromatographic (GC) results of the analyzed crude oils are shown in Fig. 7 and summarized in Table 6. Generally, the normal alkane distribution patterns can be seen in the range between $\mathrm{C}_{8}$ and $\mathrm{C}_{31}$ while maximum peaks are basically identified between $\mathrm{C}_{10}$ and $\mathrm{C}_{14}$. According to
Mobarakabad et al. (2011), it was remarked that alkanes smaller than $\mathrm{C}_{8}$ might be lost during oil sample handling. Specifically, a normal alkane distribution was identified for F9-3H oil (Fig. 7a), which has a $\mathrm{Pr} / \mathrm{Ph}$ ratio of 0.72 ; while the pattern distribution of $\mathrm{F} 15-3 \mathrm{H}$ oil indicates that the oil is mainly composed of n-alkanes with a low amount of isoprenoids alkane, Fig. 7b. The third crude oil from KG-031 well, however, has a complete distribution of the normal alkanes (Fig. 7c), but its $\mathrm{Pr} / \mathrm{Ph}$ ratio (0.89) is slightly higher. This normal alkane distribution pattern is a key feature of source rocks containing a high content of marine organic matter input (Peters et al. 2005).

The depositional environment and organic matter source are commonly identified using the $\mathrm{Pr} / \mathrm{Ph}$ ratio; $\mathrm{Pr} / \mathrm{Ph}$ ratios higher than 3 indicate oxic deposition with terrigenous organic matter input, and low $\mathrm{Pr} / \mathrm{Ph}$ ratios $(<1)$ indicate a highly saline and reducing depositional setting (Hunt 1996; Li et al. 1999). As the $\mathrm{Pr} / \mathrm{Ph}$ ratios of the Fahliyan oils are less than 0.9 , we conclude that the ' $\mathrm{F}$ ' and ' $\mathrm{KG}$ ' oils have been generated in a saline and reducing environment.

From $\mathrm{Pr} / \mathrm{nC}_{17}$ versus $\mathrm{Pr} / \mathrm{n}-\mathrm{C}_{18}$ ratio cross-plots shown on Fig. 8, the maturity, organic matter input and dependent on Tissot and Welte (1978), Peters et al. (2005), depositional environment of the Fahliyan oils were identified. Thus, in combination with the normal alkane distribution discussed above, it can be concluded that non-biodegraded hydrocarbons are present in the Fahliyan Formation. On the basis of having $\mathrm{Pr} / \mathrm{nC}_{17}$ and $\mathrm{Pr} / \mathrm{n}-\mathrm{C}_{18}$ ratios relatively low (ranging from 0.21 to 0.41 ), the analyzed oils might be originated from marine carbonate source rocks, and deposited in reducing environments with marine organic matter. This is true with what Abdullah and Connan (2002) was reported. Considering the small variance in these ratios, it is clear that these crude oils were generated from a single source rock with a high maturity level.

Based on the concept of Seifert and Moldowan (1980), the ternary $\mathrm{C}_{27}, \mathrm{C}_{28}$, and $\mathrm{C}_{29}$ regular steranes diagram was also considered to determine and confirm the depositional
Fig. 6 DHA group type distribution based on light oil fractions

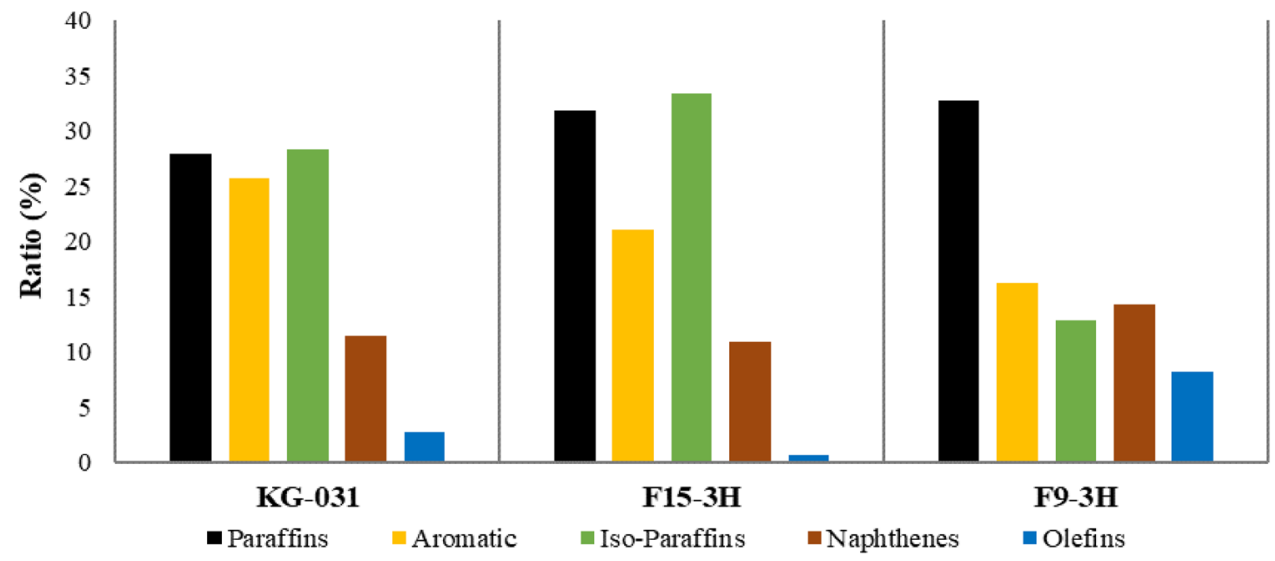


Fig. 7 Gas chromatograms of Fahliyan crude oils from ' $F$ ' and 'KG' fields
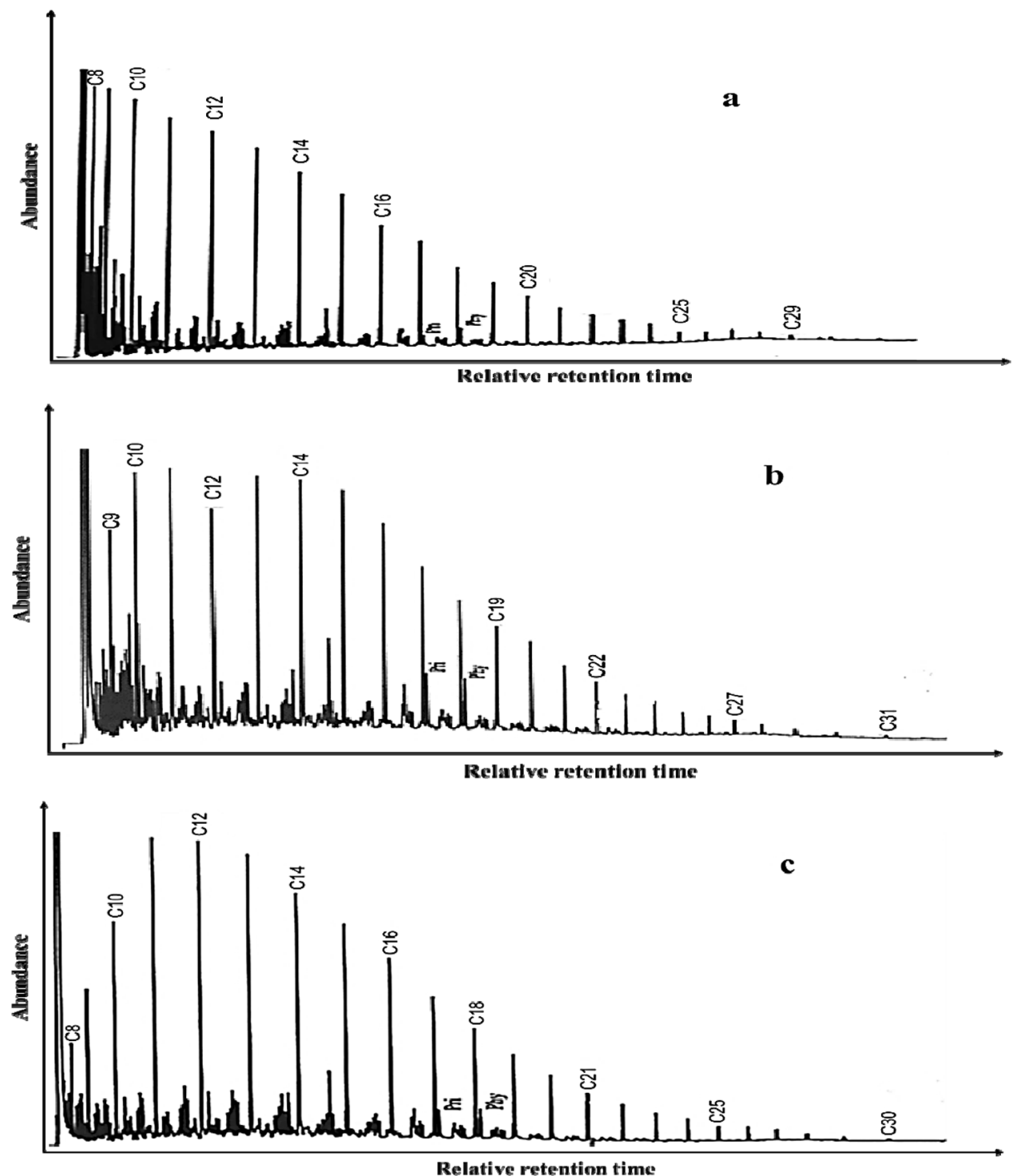

\begin{tabular}{lccccccccccc}
\hline Well & {$\left[\frac{\mathrm{Pri}}{\mathrm{C} 17}\right]$} & {$\left[\frac{\mathrm{Phy}}{\mathrm{C} 18}\right]$} & {$\left[\frac{\mathrm{Pri}}{\mathrm{Phy}}\right]$} & {$\left[\frac{\mathrm{C} 19}{\mathrm{C} 20}\right]$} & {$\left[\frac{\mathrm{C} 21}{\mathrm{C} 22}\right]$} & {$\left[\frac{\mathrm{C} 23}{\mathrm{C} 24}\right]$} & {$\left[\frac{\mathrm{C} 25}{\mathrm{C} 26}\right]$} & {$\left[\frac{\mathrm{C} 27}{\mathrm{C} 28}\right]$} & {$\left[\frac{\mathrm{C} 29}{\mathrm{C} 30}\right]$} & {$\left[\frac{\mathrm{C} 31}{\mathrm{C} 32}\right]$} & $\mathrm{CPI}$ \\
\hline KG-031 & 0.31 & 0.41 & 0.89 & 1.08 & 1.13 & 1.08 & 1.07 & 1.14 & 1.13 & 1.05 & 1.00 \\
F9-3H & 0.21 & 0.35 & 0.72 & 1.23 & 1.14 & 1.13 & 1.09 & 1.14 & 1.11 & 1.01 & 0.94 \\
F15-3H & 0.31 & 0.32 & 0.71 & 1.17 & 1.11 & 1.10 & 1.09 & 1.11 & 1.09 & 0.99 & 0.93 \\
\hline
\end{tabular}

Table 6 GC analysis results for saturate fraction of oils all analyzed oils have the same concentrations trends, i.e., $\mathrm{C}_{28}>\mathrm{C}_{29}>\mathrm{C}_{27}$.

In addition, dibenzothiophene/phenanthrene (DBT/P) versus $\mathrm{Pr} / \mathrm{Ph}$ ratios indicate the lithology of the source rock (Hughes et al. 1995), for instance carbonate rocks have a ratio higher than 1 and shales have ratios less than 1. The analyzed crude oils fall in Zone-1B of the crossplot, which indicates that the lithology of the source rock is marine carbonate and marl (Fig. 10). However, DBT/P environment of the crude oil source rocks (Fig. 9). Clearly, the oil samples from both fields were derived from a single source rock, which was deposited in an open marine environment. The $\mathrm{C}_{27}, \mathrm{C}_{28}$, and $\mathrm{C}_{29}$ steranes have approximately the same concentrations in the ' $\mathrm{F}$ ' oils $\left(\mathrm{C}_{27} \approx 23, \mathrm{C}_{28} \approx 77\right.$ and $\left.\mathrm{C}_{29} \approx 52\right)$, and varied concentrations in ' $\mathrm{KG}$ ' oil $\left(\mathrm{C}_{27} \approx 19\right.$, $\mathrm{C}_{28} \approx 81$ and $\mathrm{C}_{29} \approx 50$ ). Meanwhile, the $\mathrm{C}_{27}, \mathrm{C}_{28}$ and $\mathrm{C}_{29}$ in 


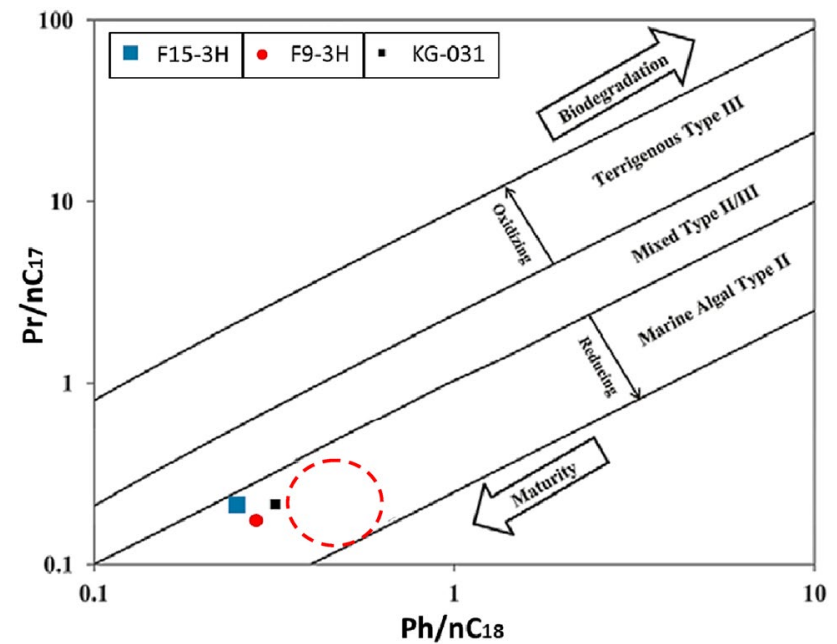

Fig. $8 \mathrm{Pr} / \mathrm{n}-\mathrm{C}_{17}$ versus $\mathrm{Ph} / \mathrm{n}-\mathrm{C}_{18}$ ratio cross-plots for the studied crude oils

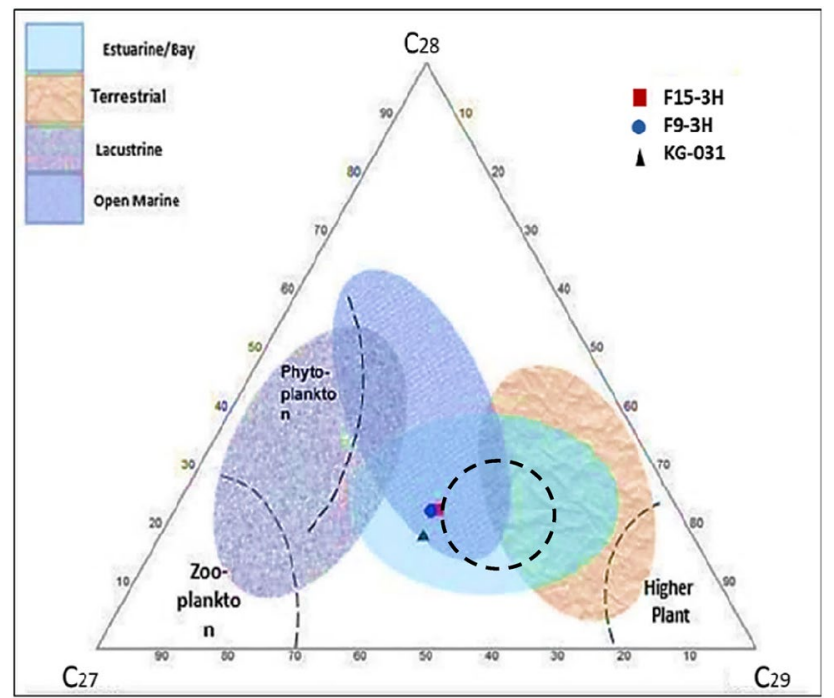

Fig. 9 Ternary diagram illustrating the relative $\mathrm{C}_{27}, \mathrm{C}_{28}$, and $\mathrm{C}_{29}$ sterane contents of the studied oil samples

is greater than 1 for the Fahliyan crude oils, this ratio ranges from 1.2 to 2.8 , representing the various source rock facies. Higher DBT/P ratios for F15-3H and KG-031 oils thus show higher carbonate content in their source rocks than in case of F9-3H oil.

\section{Thermal maturity}

For evaluation of oil maturity levels, steranes and hopanes concentrations were analyzed (Table 7). Thus, two plots were drawn, first the $\mathrm{C}_{29} \alpha \alpha \alpha 20 \mathrm{~S} /$ $(20 \mathrm{~S}+20 \mathrm{R})$ versus $\mathrm{C}_{29} \alpha \beta \beta /(\alpha \alpha \alpha+\alpha \beta \beta)$ ratios, and

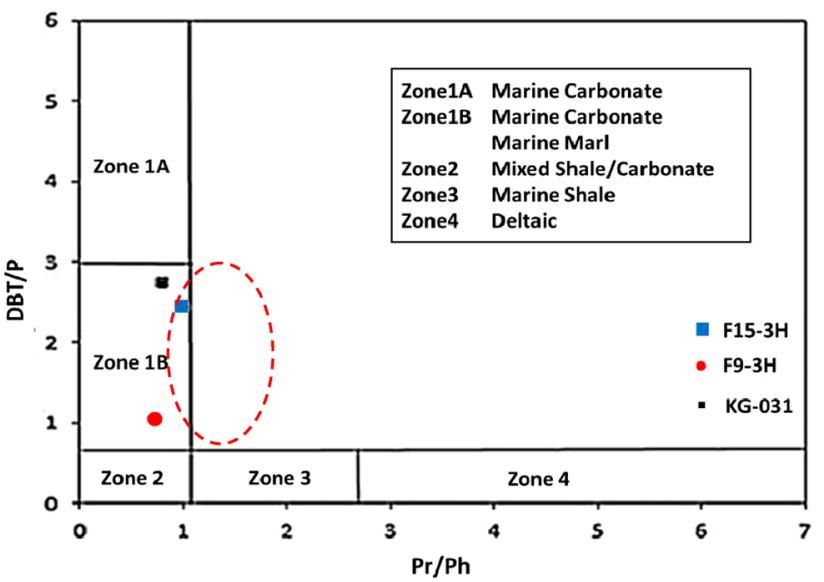

Fig. $10 \mathrm{Pr} / \mathrm{Ph}$ ratio versus DBT/P ratio cross-plot for studied oil samples (Seifert and Moldowan 1980)

second the methyldibenzothiophene (MDBT) versus $\mathrm{C}_{32}$ $22 \mathrm{~S} /(22 \mathrm{~S}+22 \mathrm{R})$ ratios as shown in Fig. 11 (Peters and Moldowan 1991; Peters et al. 2005). All oil samples are in the mature oil interval as the $\mathrm{C}_{29} \alpha \alpha \alpha 20 \mathrm{~S} /(20 \mathrm{~S}+20 \mathrm{R})$ and $C_{29} \alpha \beta \beta /(\alpha \alpha \alpha+\alpha \beta \beta)$ ratios range from $0.47-0.48$ to $0.52-0.57$, respectively (Fig. 11a). Although the methyldibenzothiophene (MDBT) ratio of F15-3H oil is lower when compared to the other oils, Fig. 11b also indicates that the source rock of the Fahliyan crude oils is well matured (Peters et al. 2005). Figure 12 expresses the relationship between $20 \mathrm{~S} /(20 \mathrm{~S}+20 \mathrm{R}), \beta \beta /(\alpha \alpha+\beta \beta)$ and $22 \mathrm{~S} /$ $(22 \mathrm{~S}+22 \mathrm{R})$ for $\mathrm{C}_{29}$ and $\mathrm{C}_{32}$ steranes and oil maturity levels. With increasing maturity, the $20 \mathrm{~S} /(20 \mathrm{~S}+20 \mathrm{R})$ and $\beta \beta /(\alpha \alpha+\beta \beta) C_{29}$ sterane ratios increase until equilibrium ratios are reached (Peters et al. 2005). Additionally, the $22 \mathrm{~S} /(22 \mathrm{~S}+22 \mathrm{R})$ ratio of $\mathrm{C}_{32}$ homohopanes increases during maturation up to 0.6 (Mashhadi and Rabbani 2015). As the measured $20 \mathrm{~S} /(20 \mathrm{~S}+20 \mathrm{R})$ and $\beta \beta /(\alpha \alpha+\beta \beta)$ for $\mathrm{C}_{29}$ sterane and $22 \mathrm{~S} /(22 \mathrm{~S}+22 \mathrm{R})$ for $\mathrm{C}_{32}$ homohopanes from the Fahliyan Formation vary from 0.47 to 0.6 , it confirms that the analyzed oil are highly mature (Fig. 12).

Furthermore, the Hopane parameters were analyzed to further identify the maturity level (Peters and Fowler 2002). We found that the variation of $\mathrm{C} 30 \mathrm{Ts} / \mathrm{C} 30 \mathrm{H}$ content in ' $\mathrm{F}$ ' and ' $\mathrm{KG}$ ' field oil is small (ranging from 0.22 to 0.26 ), Table $7 \mathrm{a}$. The Gammacerane/ $\mathrm{C}_{30-31}$ ratio varies widely (from 0.16 to 0.69 ) and it is less than 1 for all samples studied. Moreover, the $\mathrm{Ts} /(\mathrm{Ts}+\mathrm{Tm})$ ratio lies between 0.29 and 0.45 , which indicates that Fahliyan is a mature oil (Peters et al. 2005). 


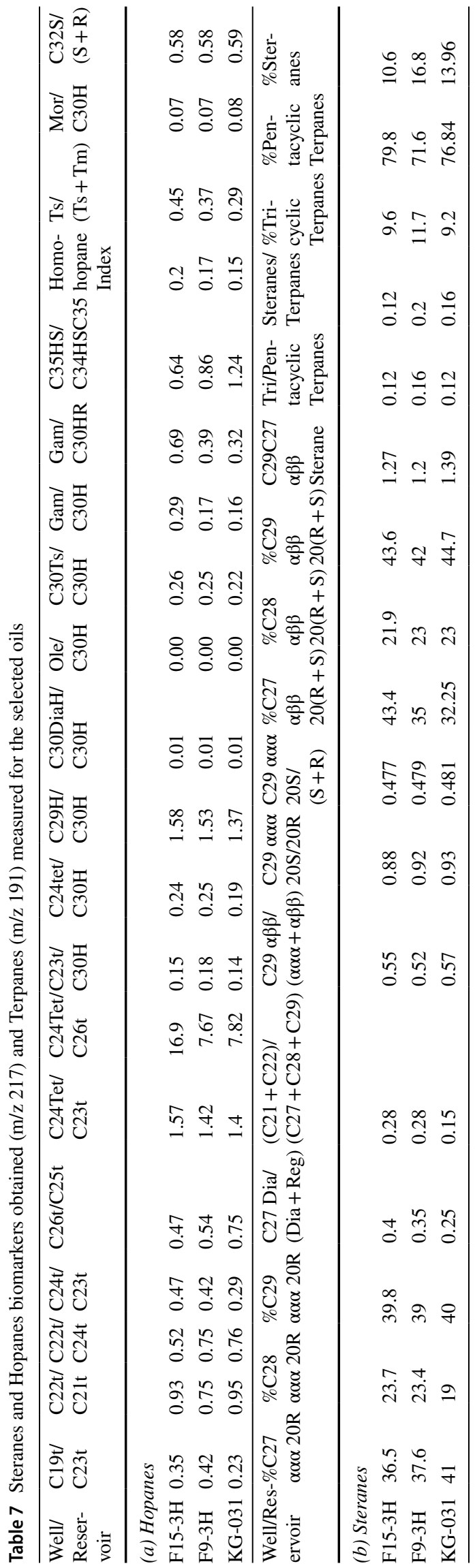

\section{Oil-source rock correlation}

As discussed above, and based on the GC hopane/sterane analysis (see Fig. 13), the oil samples were identified to stem from a carbonate-rich source rock with marine organic matter input, which deposited under marine reducing conditions to at high maturity level. In addition, the relationships between $\mathrm{Pr} / \mathrm{Ph}, \mathrm{C}_{29} / \mathrm{C}_{30}$ hopane, DBT/P, $\mathrm{Pr} / \mathrm{nC}_{17}$ and $\mathrm{Ph} / \mathrm{nC}_{18}$ illustrate that the carbonate source rock was deposited in a reducing marine environment. Considering the hopane/sterane parameters on the star diagrams, the Fahliyan oils from the two different fields are very similar and show almost the same hopane/sterane ratios (Fig. 13). This also suggests that the analyzed crude oils were formed from the same single source rock.

Diasterane/sterane ratios are commonly used to distinguish the type of source rock from which the hydrocarbons were generated (i.e., carbonate or clastic), Seifert and Moldowan (1980), Gratzer et al. (2011); low diasterane/sterane ratios indicate anoxic clay-poor or carbonate source rock, while high diasterane/sterane ratios suggest that the hydrocarbon derived from clay-rich source rocks. Furthermore, in some crude oils, high thermal maturity and/or heavy biodegradation results in a high diasterane/ sterane ratio (Zumberge 1984; Alavi 2007). In this work, the $\mathrm{C}_{27} \mathrm{Dia} /(\mathrm{Dia}+\mathrm{Reg})$ versus $\mathrm{C}_{29} / \mathrm{C}_{30}$ hopane ratios have been plotted to identify the depositional environment of the oil source rocks (Fig. 14a). It can be seen that the Fahliyan oils have low diasterane/sterane ratios, suggesting that they were formed in carbonate source rocks. $\mathrm{C}_{22} / \mathrm{C}_{21}$ and $\mathrm{C}_{24} / \mathrm{C}_{23}$ tricyclic terpane ratios can also be used to identify the type of source rock; for shaly source rock the $\mathrm{C}_{22} / \mathrm{C}_{21}$ tricyclic terpane ratio is less than 0.5 , whereas ratios higher than 0.5 indicate carbonate source rock (Grantham and Wakefield 1988). Thus, the $\mathrm{C}_{22} \mathrm{t} /$ $\mathrm{C}_{21} \mathrm{t}$ ratios (ranging from 0.75 to 0.95 ) versus the $\mathrm{C}_{24} \mathrm{t}$ / $\mathrm{C}_{23}$ t ratios (ranging from 0.29 to 0.47 ) were plotted in Fig. 14b. Clearly, all oil samples were generated from marl-carbonate source rocks, consistent with the hopane analysis.

In order to determine the age of the source rock, $\mathrm{C}_{28} /$ $\mathrm{C}_{29}$ regular sterane ratios were examined; ratios $<0.7$ indicate Paleozoic and Jurassic ages, while ratios $>0.7$ indicate Upper Jurassic to Cretaceous-Tertiary ages (Zumberge 1984). Here, $\% \mathrm{C}_{28}$ regular sterane versus $\mathrm{C} 28 / \mathrm{C} 29$ sterane ratios ranged from $0.38-0.61$ and $18.55-25.87$, respectively. Thus, these crude oils accumulated in deeper reservoirs, and originating from late Jurassic or early Cretaceous rocks (Fig. 15). 

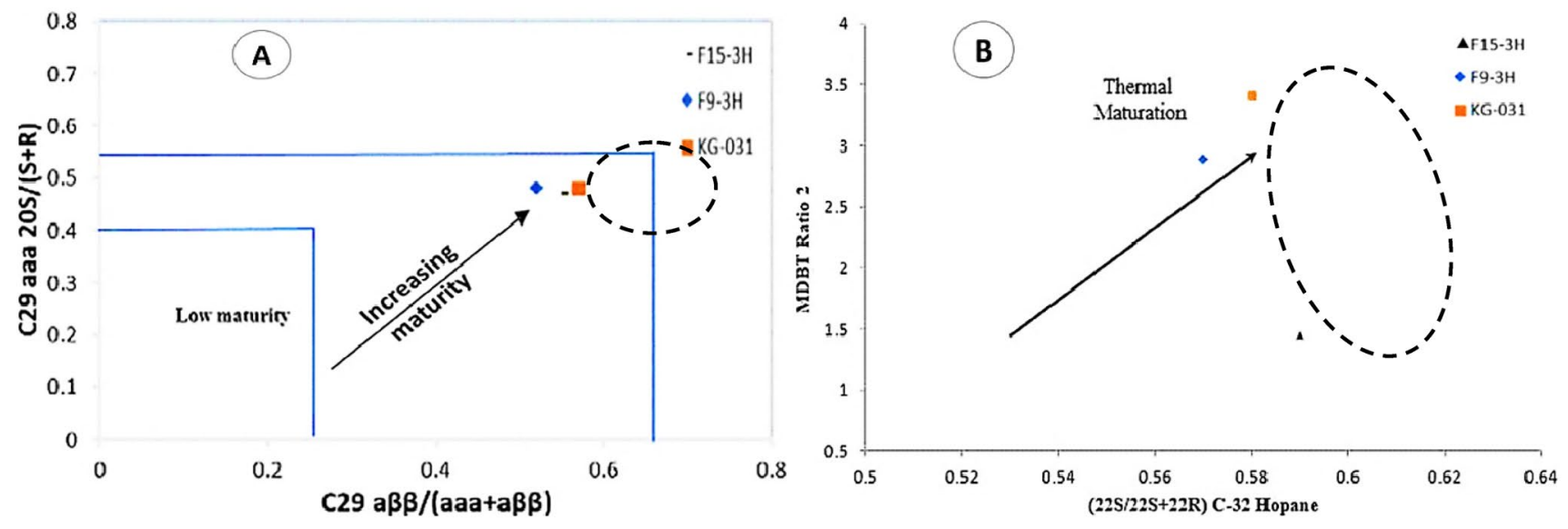

Fig. 11 Cross-plots showing the maturity level of the oil samples studied based on a $C_{29}$ aaaS/(aaaS + aaaR) versus $C_{29} \beta \beta /(\beta \beta+\alpha \alpha)$ steranes ratio and $\mathbf{b}$ MDBT 2 versus $\mathrm{C} 22 \mathrm{~S} /(22 \mathrm{~S}+22 \mathrm{R}) \mathrm{C}_{32}$ Hopanes ratio (Peters et al. 2005)
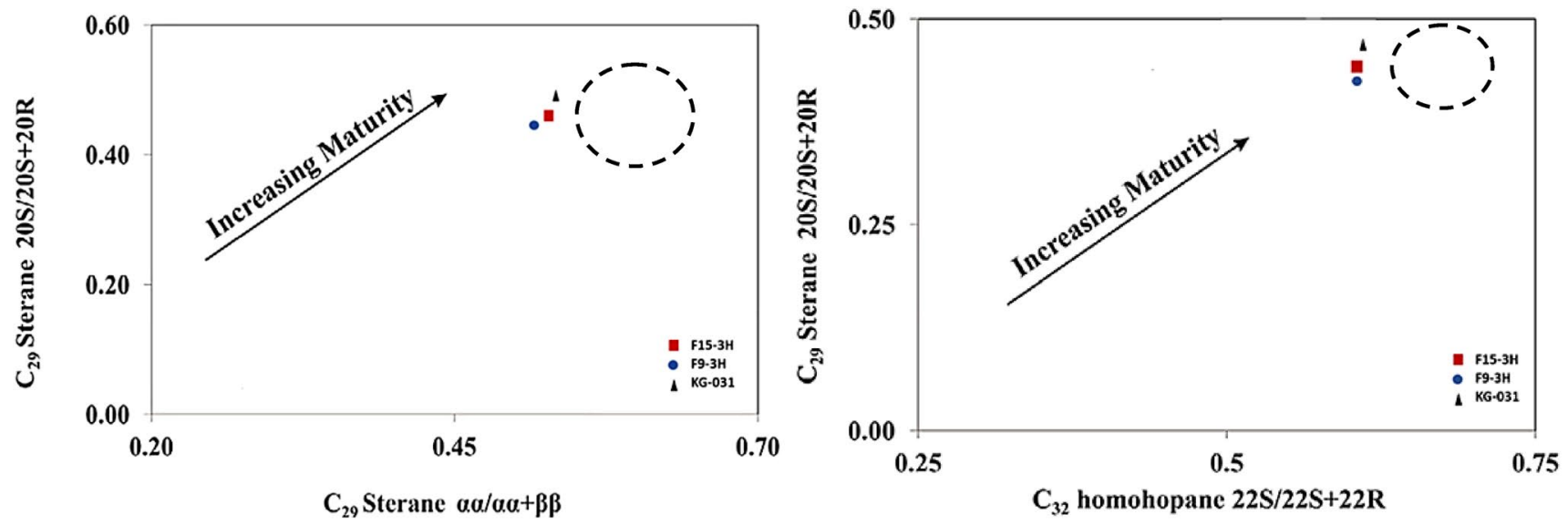

Fig. 12 Comparison of the thermal maturity of the studied Cretaceous source rocks and Fahliyan oils

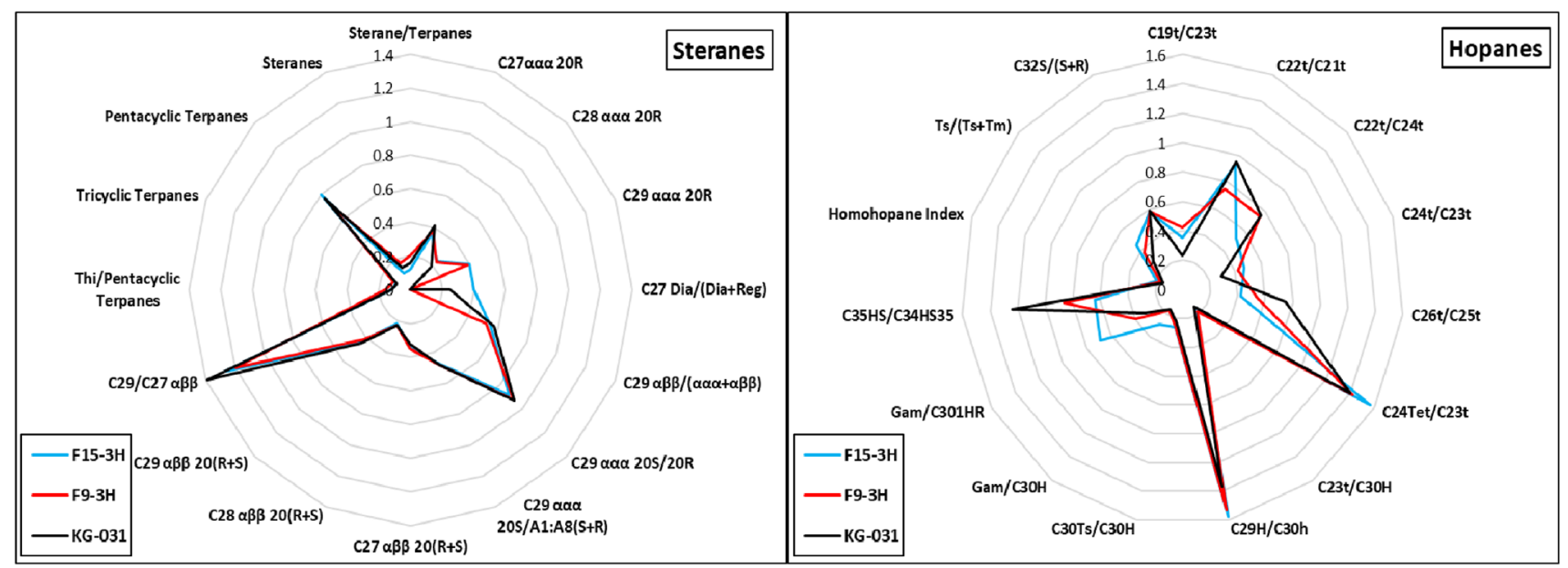

Fig. 13 Steranes (left) and Hopanes (right) parameters of the studied oils 

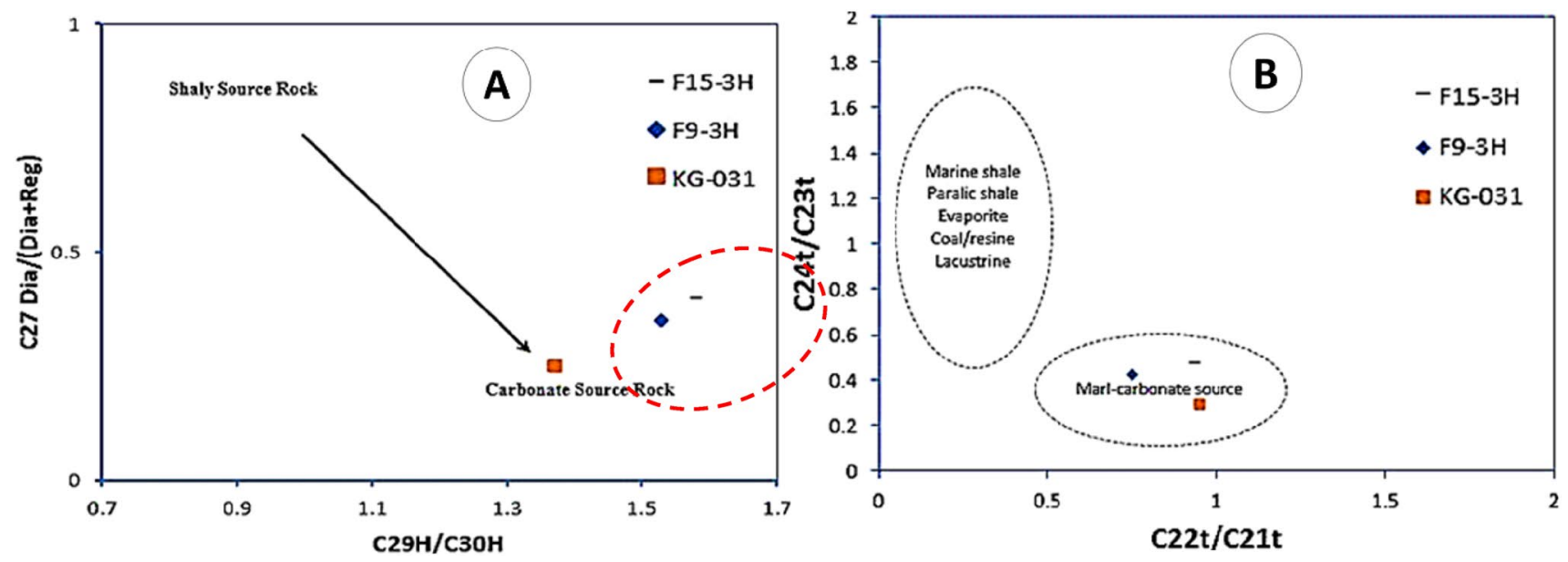

Fig. 14 Biomarkers cross-plot of a $C_{27}$ diasterane/ $C_{27}$ diasteranes versus $C_{29}$ norhopane/ $C_{30}$ hopane ratio $(29 H / 30 H)$, and b $C_{24} t / C_{23}$ t versus $\mathrm{C}_{22} \mathrm{t} / \mathrm{C}_{21} \mathrm{t}$ ratios of tricyclic terpanes

\section{Conclusions}

Multiple major Fahliyan reservoirs have been identified in the NW region of the Persian Gulf (Adabi et al. 2010; Abedpour et al. 2016; Feghi et al. 2012). However, the origin, source rock and maturity of the oil within this formation are only poorly understood. Thus, in this study, a detailed petroleum geochemical analysis of three selected crude oils from Fahliyan reservoirs in SW Iran has been performed. In this way, it was verified that the hydrocarbon in these reservoirs was generated from the late Jurassic

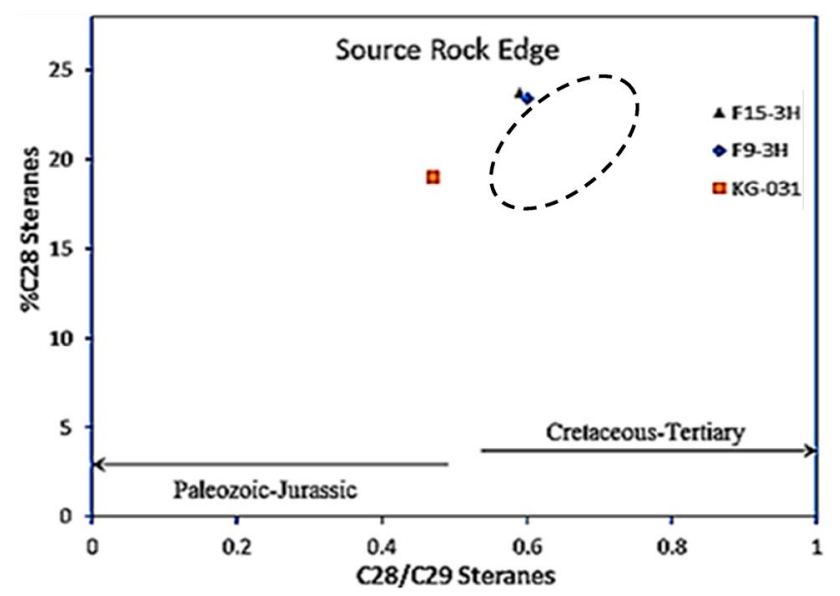

Fig. $15 \mathrm{C}_{28} / \mathrm{C}_{29}$ versus $\% \mathrm{C}_{28}$ regular sterane ratios indicating the age of the source rock to early Cretaceous. In addition, the oil bulk properties and biomarkers were characterized, and an oil-oil and oil-source rock correlations study was carried out between the three crude oils and the source rock. From this extensive analysis, it is clear that all oils are nonbiodegraded with high maturity, have a high sulfur content and were generated in carbonate source rocks containing kerogen type II. The source rock again was deposited under marine reducing conditions with marine organic matter as the dominant input.

Funding There is no funding received for this project.

Open Access This article is licensed under a Creative Commons Attribution 4.0 International License, which permits use, sharing, adaptation, distribution and reproduction in any medium or format, as long as you give appropriate credit to the original author(s) and the source, provide a link to the Creative Commons licence, and indicate if changes were made. The images or other third party material in this article are included in the article's Creative Commons licence, unless indicated otherwise in a credit line to the material. If material is not included in the article's Creative Commons licence and your intended use is not permitted by statutory regulation or exceeds the permitted use, you will need to obtain permission directly from the copyright holder. To view a copy of this licence, visit http://creativecommons.org/licenses/by/4.0/.

\section{References}

Abdullah FH, Connan J (2002) Geochemical study of some cretaceous rocks from Kuwait: comparison with oils from cretaceous and jurassic reservoirs. Org Geochem 33(2):125-148 
Abedpour M, Afghah M, Ahmadi V, Dehghanian M (2016) Biostratigraphic and lithostratigraphic study of fahliyan formation in KuhE-Siah (Arsenjan area, North-East of fars province). Open J Geology 06(12):1605-1618. https://doi.org/10.4236/ojg.2016.612114

Abyat A, Baghbani D, Afghah M, Ghadimvand NK, Feghi A (2012) Microbiostratigraphy and lithostratigraphy of fahliyan and gadvan formations in Kuh-e-Surmeh (Zagros basin, Southwest Iran). Adv Environ Biol 6(12):3078-3086

Abyat A, Baghbani D, Ghadimvand NK, Feghi A (2014) Microfacies, depositional environment, sequence stratigraphy of the fahliyan and gadvan formations, Kuh-e-Surmeh section (Zagros basin, Southwest Iran). Himalian Geology 35(1):82-89

Adabi M, Salehi M, Ghabeishavi A (2010) Depositional environment, sequence stratigraphy and geochemistry of Lower cretaceous carbonates (fahliyan formation), South-West Iran. J Asian Earth Sci 39(3): $148-160$

Alavi M (2007) Structures of the zagros fold-thrust belt in Iran. Am J Sci 307(9):1064-1095

Amijaya H, Schwarzbauer J, Littke R (2006) Organic geochemistry of lower suban coal seam, south sumatra basin, Indonesia: palaeoecological and thermal metamorphism implications. Org Geochem 37:261-279

Aubourg C, Smith B, Bakhtari H, Guya N, Eshragi A, Lallemant S, Molinaro M, Braud X, Delaunay S (2004) Post-miocene shortening pictured by magnetic fabric across the zagrosmakran syntaxis (Iran). Geol Soc Am 383:17-40

Bahroudi A, Koyi HA (2003) Effect of spatial distribution of Hormuz salt on deformation style in the zagros fold and thrust belt: an analogue modelling approach. J Geol Soc Lond 160:719-733. https://doi.org/10.1144/0016-764902-135

Baniasad A, Rabbani AR, Moallemi SA, Soleimany B, Rashidi M (2017) Petroleum system analysis of the northwestern part of the Persian Gulf, Iranian sector. Org Geochem 107:69-85

Bordenave ML (2003) Gas prospective areas in the Zagros domain of Iran and in the gulf Iranian waters. Am Assoc Pet Geol Annu Meet Houst Tex. https://doi.org/10.1080/10916466.2010.504936

Feghhi A, Habibnia B, Bakhtiar HA (2012) Sedimentological studies and reservoir potential of the fahliyan formation in the marun oil field, north dezful embayment, zagros basin Southwest Iran. Pet Sci Technol 30(12):1262-1273

Grantham PJ, Wakefield LL (1988) Variations in the sterane carbon number distributions of marine source rock derived crude oils through geological time. Org Geochem 12:61-73

Gratzer R, Bechtel A, Sachsenhofer RF, Linzer H, Reischenbacher D, Schulz H (2011) Oil-oil and oil-source rock correlations in the alpine foreland basin of Austria: insights from biomarker and stable carbon isotope studies. Mar Pet Geol 28(6):1171-1186

Hughes WB, Holba AG, Dzou LIP (1995) The ratios of dibenzothiophene to phenanthrene and pristane to phytane as indicators of depositional environment and lithology of petroleum source rocks. Geochim Cosmochim Acta 59:3581-3598

Hunt J (1996) Petroleum geochemistry and geology. W.H. Freeman and Company, New York, p 743

Jamalian M, Adabi MH (2014) Geochemistry, microfacies and diagenetic evidences for original aragonite mineralogy and open diagenetic system of lower cretaceous carbonates Fahliyan Formation (Kuh-e Siah area, Zagros basin, South Iran). Carbonates Evaporites 30(1):77-98

Jamalian M, Adabi MH, Moussavi MR, Sadeghi A, Baghbani D, Ariyafar B (2010) Facies characteristic and paleoenvironmental reconstruction of the fahliyan formation, lower cretaceous, in the Kuh-e Siah area, Zagros basin, southern Iran. Facies 57(1):101-122

James GA, Wynd JG (1965) Stratigraphic nomenclature of Iranian oil consortium agreement area. Am Assoc Pet Geol Bull 49:2182-2245
Kamali MR, Abolghasemi A, Bagheri R, Kadkhodayi A (2013) Petroleum geochemistry and oil-oil correlation of the fahliyan and surmeh reservoirs in the garangan and chilingar oilfields, the dezful embayment (Sw Iran). J Pet Explor Prod Technol 3(2):85-92

Kavoosi MA, Feizi A, Jamali MA (2006) Diagenetic processes and their position in sequence stratigraphy of the fahliyan formation in mansuri, Ab-Teymour and Ahwaz fields. In: 26th symposium of geological society of Iran

Kondroud KN, Lasemi Y (2008) Sequence stratigraphic control on prolific HC reservoir development Southwest Iran. Oil Gas J 106(1):34-38

Lewan MD (1984) Factors controlling the proportionality of vanadium and nickel in crude oils. Geochim Cosmochim Acta 48:2231-2238

Li MW, Lin RZ, Liao YS et al (1999) Organic geochemistry of oils and condensates in the kekeya field, southwest depression of the tarim basin. China Org Geochem 30(1):15-37

Liu Q, Song Y, Jiang L, Cao T, Chen Z, Xiao D, Han G, Ji W, Gao F, Wang P (2017) Geochemistry and correlation of oils and source rocks in banqiao sag, huanghua depression, northern China. Int J Coal Geol 176-177:49-68

Mahbaz S, Sardar H, Memarian H (2012) Determination of a rock physics model for the carbonate fahliyan formation in two oil wells in southwestern Iran. Explor Geophys 43(1):47

Mashhadi ZS, Rabbani AR (2015) Organic geochemistry of crude oils and cretaceous source rocks in the Iranian sector of the persian gulf: an oil-oil and oil-source rock correlation study. Int J Coal Geol 146:118-144

Moallemi SA (2000) Microfacies, sedimentary environment and variation of 2 porosity of fahliyan formation in khark area. Thesis submitted for the master of science at the university of Azad, Tehran, Iran (in Persian), p 107

Mobarakabad AF, Bechtel A, Gratzer R, Mohsenian E, Sachsenhofer RF (2011) Geochemistry and origin of crude oils and condensates from the central persian gulf, offshore Iran. J Pet Geol 34:261-275

Peters KE, Fowler MG (2002) Applications of petroleum geochemistry to exploration and reservoir management. Org Geochem 33(1):5-36

Peters KE, Moldowan JM (1991) Effects of source, thermal maturity, and biodegradation on the distribution and isomerization of homohopanes in petroleum. Org Geochem 17:47-61

Peters KE, Walters CC, Moldowan JM (2005) The biomarker guide, 2nd edn. Cambridge University Press, New York

Rabbani AR, Kotarba MJ, Baniasad AR, Hosseiny E, Wieclaw D (2014) Geochemical characteristics and genetic types of the crude oils from the Iranian sector of the persian gulf. Org Geochem 70:29-43

Sabouhi MDJ, Taati Qurayem F, Aminzadeh A (2009) Facies analysis of fahliyan formation in north dezful embayment, southwest Iran: implications for porosity distribution. Geophys Res Abstr 11(1):1604

Schwarzbauer J, Littke R, Weigelt V (2000) Identification of specific organic contaminants for estimating the contribution of the elbe river to the pollution of the German bight. Org Geochem 31:1713-1731

Seifert WK, Moldowan JM (1980) The effect of thermal stress on source-rock quality as measured by hopane stereochemistry. Phys Chem Earth 12:229-237

Shakeri A, Parham S (2013) Reservoir characterization and quality controlling factors of the fahliyan formation located in southwest Iran. J Sci 24:135-148

Shakib SS (1994) Paleoenvironmental and biostratigraphic significance of Foraminifera associations from the Early Cretaceous sediments of Southwest Iran. In: Simmons MD (ed) Micropalaeontology and Hydrocarbon Exploration in Middle East. Chapman and Hall, p 418 
Sherkati S, Molinaro M, Frizon De Lamotte D, Letouzey J (2005) Detachment folding in the central and eastern zagros fold-belt (Iran): salt mobility, multiple detachments and late basement control. J Struct Geol 27:1680-1696

Soleimani B, Hassani-Giv M, Abdollahi Fard I (2017) Formation pore pressure variation of the neocomian sedimentary succession (the Fahliyan Formation) in the Abadan Plain Basin, SW of Iran. Geofluids 2017:1-13
Tissot BP, Welte DH (1978) Petroleum formation and occurrence: a new approach to oil and gas exploration. Springer, Berlin

Zumberge JE (1984) Source rocks of the La Luna (Upper Cretaceous) in the Middle Magdalena Valley, Colombia, Palacas. In: Palacas JG (ed) Geochemistry and Source Rock Potential of Carbonate Rocks. American Association of Petroleum Geologists, pp $127-133$ 